\title{
P53 PROTEIN LEVEL AND EVIDENCE OF ONGOING COAGULATION AMONG HIV-INFECTED PERSONS ACCESSING TREATMENT AT UNIVERSITY OF CALABAR TEACHING HOSPITAL NIGERIA
}

\author{
Euphoria Akwiwu ( $\nabla$ ecakwiwu@gmail.com ) \\ Anthony Okafor \\ University of Calabar Teaching Hospital \\ Josephine Akpotuzor \\ University of Calabar
}

University of Calabar https://orcid.org/0000-0001-6097-557X

\section{Research note}

Keywords: Coagulation, HIV infection, immunosuppression.

Posted Date: August 2nd, 2019

DOl: https://doi.org/10.21203/rs.2.12309/v1

License: (c) (i) This work is licensed under a Creative Commons Attribution 4.0 International License.

Read Full License

Version of Record: A version of this preprint was published at Journal of Cancer and Tumor International on November 26th, 2019. See the published version at https://doi.org/10.9734/jcti/2019/v9i330111. 


\section{Abstract}

Objective The human immunodeficiency virus (HIV) infection has been associated with hemostatic disturbance. In Nigeria, particularly Calabar, not much is known about the nature of these derangement among infected subjects. This study was carried out with a view to assessing tumour suppressing activity and ongoing coagulation among HIV-infected subjects. The data presented is a side product of investigation on morbidity indicators among persons living with HIV infection in Calabar, Nigeria. Result The CD4 cell count and P53 protein level reduced while D-dimer level increased in HIV infection. Platelet count also reduced while platelet distribution width increased with the condition. While CD4 cell count improved with Highly Active Antiretroviral Therapy administration, D-dimer level, mean platelet volume and platelet distribution width reduced. This study observed reduced tumour suppression and increased coagulation activities alongside immunosuppression in HIV infection. Keywords: Coagulation, HIV infection, immunosuppression.

\section{Introduction}

Early intervention in the management of HIV infection is a challenge in resource-poor settings often due to late presentation to hospitals and inadequate screening of the populace $[1,2,3]$. Among the infected persons in our local population, widespread derangement in biomarkers and morbidity indicators that mirror poor health status prevail $[4,5]$. Coagulation disturbances and cancer have been identified as factors for increased mortality among people living with HIV infection. Impaired immunity and the development of these other morbidities are thought to reflect an unending cycle that eventually progresses HIV infection to AIDS [6, 7, 8, 9,10]. In Nigeria, particularly Calabar, not much is known about the nature of the hemostatic disturbance seen in HIV infection. There is also paucity of information on levels of cancer biomarkers among infected subjects. This study was carried out with a view to assessing tumour suppressing activity and ongoing coagulation among HIV-infected subjects.

The data presented is part of a research on morbidity indicators among persons living with HIV infection attending clinics at University of Calabar Teaching Hospital, Calabar Nigeria.

\section{Methods}

Ninety persons living with HIV infection who were attending clinics at University of Calabar Teaching Hospital were enrolled with ninety age and sex-matched HIV sero-negative individuals who served as control subjects. The enrollment of persons living with HIV infection took into consideration certain subgroups on the basis of commencement of highly active antiretroviral therapy (HAART). Thirty persons were newly diagnosed and were yet to embark on HAART. The remaining 60 were already undergoing treatment. Blood specimen was collected from each participant for analyses of CD4 cell and full blood counts by automation, serum was used for the assays of P53 protein and D-dimer levels using enzymelinked immunosorbent assay test kits. Data analysis was done using SPSS version 22.0. Student t-test was used to compare means between test and control subjects. One-way analysis of variance was used 
to compare means across the HAART-naïve and two other groups on different HAART protocols. Pearson's correlation was used to analyze relationships. Statistical significance was drawn at a $p \leq 0.05$.

\section{Results}

Persons living with HIV infection who participated in this study were adults from eighteen years and above. The age group with the highest number of participants was 36-45yeaars which featured $34.4 \%$ (31 out of 90 ) of all the persons. This was followed by age group 26-35years which had $31.1 \%$ (28 out of 90 ) of the subjects. The least number of participants, $7.8 \%$ (7out of 90 ) came from the group above 55years of age. More females $63.3 \%$ (57 out of 90 ) than males $36.7 \%$ (33 out of 90 ) were observed accessing medical care at the study center. In addition, more than half of these persons were married $60 \%$ (54 out of 90) at the time of the study. A third of the persons living with HIV infection were enrolled from those newly diagnosed. The remaining 60 were already undergoing treatment. Two HAART protocols were observed among subjects who were being treated; Tenofovir+Lamivudine+Efavirenz (TLE) and Lamivudine+Zidovudine+Nevirapine (LZN). Subjects on TLE were 48.3\% (29 out 60), while those on LZN were $51.7 \%$ (31 out of 60 ) (Table 1 in the Supplementary Files).

The CD4 cell count and P53 protein level were found to be reduced while D-dimer level increased in HIV infection. The platelet parameters considered in this study were platelet count, mean platelet volume (MPV) and platelet distribution width (PDW). Platelet count was observed to be reduced while platelet distribution width (PDW) increased with the condition (Table 2 in the Supplementary Files).

Subjects on highly active antiretroviral therapy (HAART) were either taking Tenofovir+Lamivudine+Efavirenz (TLE) or Lamivudine+Zidovudine+Nevirapine (LZN). Both drug combinations impacted similarly on the measured parameters. While CD4 cell count improved with HAART administration, D-dimer level, mean platelet volume (MPV) and PDW reduced (Table 3 in the Supplementary Files).

\section{Discussion}

Although HIV infection affects all ages, the current study enrolled persons from eighteen years of age and above mainly for the ease of obtaining consent. The age group with the highest number of participants was $36-45 y e a a r s$ which featured $34.4 \%$ persons. This was followed closely by age group $26-35 y e a r s$ which had $31.1 \%$ subjects. Altogether, the age group between $26-45$ years constituted $65.5 \%$. This frequency pattern for age, combined with that for gender (63.3\% female participation) as well as that for marital status ( $60 \%$ of married persons) reveals a significant pattern. It implies that among adults living with HIV infection, women of child-bearing age constitute the highest group receiving medical attention for HIV infection. This trend has implications for the control of HIV infection in this locality as the risk of mother to child transmission could be better managed within conventional health facilities. 
This study observed alongside a lower value of CD4 cell count, reduced serum p53 protein level. In the progression of HIV infection to AIDS, both decline in immunity and the development of cancer are considered important morbidity and mortality factors $[6,8,9,10,11]$. In resource-poor settings, cancer screening among HIV-infected persons is yet to commence despite the need to monitor this aspect of health for infected persons [12]. The p53 gene and its protein play a significant role in the immunosuppression of cancer and is also kwon to mediate against the replication of the human immunodeficiency virus, thus serving as a host-restriction factor. It is therefore thought that the silencing of the p53 pathway promotes both viral replication and disease progression in HIV infection $[13,14]$. The two HAART protocols in use at the health facility were observed to improve the CD4 cell count but showed no significant variation for the serum p53 protein. There may be need to go beyond this stage of treatment if tumour immunosuppression is to be addressed. This could impact on disease progression from HIV infection to AIDS in Africa.

In addition to the reduced serum p53 protein, the studied population showed evidence of activated coagulation as observed in the lower platelet count but higher PDW and D-Dimer values. Although the finding of lower platelet count could arise from insufficient production as well as increased consumption, the observation of higher PDW value suggests the later. The PDW represents the variability in platelet size and is thought to be an important marker of platelet activation $[7,15,16,17,18,19]$ More importantly, Ddimer is the degradation product of fibrinogen and fibrin during fibrinolysis. Although there are various fibrin-degradation products that result from plasmin-mediated breakdown, D-dimers is considered a specific marker for fibrinolysis in that only fragments originating from fibrin polymers that had undergone factor XIII mediated cross-linking retain an intact covalent bond between two adjacent $D$ domains; hence the term D-dimers. It therefore reflects ongoing activation of the hemostatic system and more specifically represent breakdown products of cross-linked fibrin clot formation $[20,21,22]$. The D-dimer, MPV and PDW varied across the HAART groups in relation to the HAART-Naïve group. The drugs impacted positively on the coagulation parameters studied, thus suggesting a better hemostatic state among persons living with HIV infection who are on HAART compared to those yet to commence HAART.

\section{Limitations}

The study could not adopt a follow up approach in assessing the impact of therapy on the measured parameters.

\section{List Of Abbreviations}

AIDS Acquired immunodeficiency syndrome

ANOVA Analysis of variance

CD4 Cluster of differentiation

HAART Highly active antiretroviral therapy 
HIV Human immunodeficiency virus

LZN Lamivudine+Zidovudine+Nevirapine

MPV Mean platelet volume

PDW Platelet distribution width (PDW)

TLE Tenofovir+Lamivudine+Efavirenz

\section{Declarations}

\section{Ethics approval and consent to participate}

Ethical approval was obtained from University of Calabar Teaching Hospital Health Research Ethics Committee (UCTH/HREC/33/553), while written informed consent was obtained from each participant.

\section{Consent for publication}

Not applicable

\section{Availability of data and materials}

The authors do not wish to share their data because some aspects of the research are yet to be completed.

\section{Competing interests}

The authors declare that they have no competing interests

\section{Funding}

Self-funded

\section{Authors' contributions}

E.C.A., A.O.O. and J.O.A. conceptualized and designed the research. E.C.A. wrote the original draft of the paper. E.C.A. and A.O. O. were responsible for sample collection/ analyses and data analyses. J.O.A. reviewed and edited the paper. All authors have read and approved the manuscript for submission.

\section{Acknowledgements}

Not applicable

\section{References}


1 Akwiwu EC, Akpotuzor JO. Determinants of voluntary uptake of HIV counseling and testing among infected persons in Calabar, Nigerian. Contemporary Journal of Inter-disciplinary Studies 2018; 7(4): 4854. 2 Ugochi VE, Akwiwu EC, Akpotuzor JO. Risk factors associated with HIV transmission and infection among persons aged 0-17 years in Calabar Metropolis of Nigeria. Journal of Medical and Dental Science Research 2018; 5 (5): 27-30. 3 Akwiwu EC, Akpotuzor JO, Okon JE, Egharevba O. Iron studies of HIVinfected subjects in Calabar- A Nigerian Perspective. Journal of Medical Science and Clinical Research 2017; 3(5): 19572-19577. 4 Ekanem BP, Akwiwu EC, Akpotuzor JO. Derangement in some antioxidants among HIV-infected persons in Calabar, Nigeria. Journal of Pharmacy and Biological Sciences 2018; 13 (3); 60-63. 5 Piwoz EG, Prebel EA. HIV/AIDS and nutrition: a review of the Literature and recommendations for nutritional care and support in sub-saharan Africa. Washington DC Academy for Educational Development online report 2000. 6 Biggar RJ, Chaturvedi AK, Geodert JJ, Engels EA. AIDSrelated cancer and severity of immunosuppression in persons with AIDS. Journal of National Cancer Institute 2007; 99(12): 962-972. 7 Vagdatli E, Gounari E, Lazaridou E, Katsibourilia E, Tsikopoulou F, Labrianou I. Platelet distribution width: a simple, practical and specific marker of activation of coagulation. HippoKratia, 2010; 14(1):28-32 8 Cummins NW, Badley AN. Mechanisms of HIV-associated lymphocyte apoptosis. Cell Death Disease, 2010; 1:e99. 9 Riedel DT, Mwangi El, Fantry LE, Alexander C, Hossain MB, Pauza CD et al. High cancer-related morality in an urban, predominantly African American, HIV-infected population. AIDS, 2013; 27(1): 1109-1171. 10 Coghill A, Shiels MS, Suneja G, Engels EA. Elevated Cancer-specific Mortality among HIV-infected Persons in the US. Journal of Clinical Oncology 2015; 33(21):2376-83. 11 Pinzone MR, Fiorica F, Dirose M, Malaguanera L, Cacopardo B, Zanghi C et al. Non-AIDS-defining cancers among HIV-infected people. European Review of Medical and Pharmacology Science, 2012; 16(10): 1377-1388. 12 Yang J, Su S, Zhao H, Wang D, Wang J, Zhang F et al. Prevalence and mortality of cancer among HIV-infected in patients in Beijing, China. British Medical Centre of Infectious Disease, 2016; 16: 1416-1423. 13 Theoret MR, Cohen CJ, Nahvi AV, Ngo LT, Suri KB, Powell DJ Jr. et al. Relationship between p53 overexpression of cancers and recognition by anti-p53 T cell receptortransduced T cells. Human Genetic Therapy, 2008; 19(11), 1219-1232. 14 Yoon CH, Kim SY, Byeon SE, Jeong Y, Lee J, Kim KP et al. P53-derived host restriction of HIV-1 replication by protein kinase R-mediated Tat phosphorylation and inactivation. Journal of Virology, 2015; 89(8): 4262-4280 15 De Luca G, Venegoni L, lorio S, Secco GG, Cassetti E, Verdoia M et al. (Novara Atherosclerosis Study Group). Platelet distribution width and the extent of coronary artery disease: results from a large prospective study. Platelets, 2010; 21(7):508-514. 16 Farias MG, Schunck EG, Dal Bó S, de Castro SM. Definition of reference ranges for the platelet distribution width (PDW): A local need. Clinical Chemistry and Laboratory Medicine,2010; 48(2):255-257. 17 Harsha MM, Chaithra SP. Thrombocytopenia in HIV infected patients and its correlation with clinical and immunological status. Journal of Evolution of Medical and Dental Sciences, 2013; 2 (27) 5035-5041. 18 Aydogan A, Akkucuk S, Arica S, Motor S, Karakus A, Ozkan OV. et al. The Analysis of Mean Platelet Volume and Platelet Distribution Width Levels in Appendicitis. Indian Journal of Surgery: 2015; 77(2):495-500. 19 Osime EO, Oresanja 00, Okwara BU. Packed cell volume Platelet count, PT, PTTK and Fibrinogen concentration of HIV positive patients on antiretroviral drugs. Pakistan Journal of Medical Sciences, 2015; 31(6): 1533-1536. 20 Gaffney PJ. Fibrin degradation products; A review of structures found in vitro and in vivo. Annals of New York Academy of Science, 2001; 
936:594-610 21 Borges AH., O'Connor JL, Phillips AN, Baker JV, Vjecha MJ, Losso MH. et al. Factors associated with D-dimer levels in HIV-infected individuals. PLOS ONE, 2014; 13: 9-13. 22 Riley RS. Widely used types and clinical applications of D-Dimer assay. Laboratory Medicine, 2016; 47(2):90-102.

\section{Tables}

Due to technical limitations, tables are only available as a download in the supplemental files section.

\section{Supplementary Files}

This is a list of supplementary files associated with this preprint. Click to download.

- Table1.jpg

- Table3.jpg

- Table2.jpg 